\title{
Defective insulin secretion by chronic glucagon receptor activation in glucose intolerant mice
}

\author{
Linda Ahlkvist', Bilal Omar ${ }^{1}$, Anders Valeur ${ }^{2}$, Keld Fosgerau ${ }^{2}$ and Bo Ahrén ${ }^{1}$ \\ 1Department of Clinical Sciences, Biomedical Center, Lund University, SE 22184 Lund, Sweden \\ ${ }^{2}$ Zealand Pharma A/S, Research and Development, DK-2600 Glostrup, Denmark
}

Correspondence should be addressed to L Ahlkvist

Email

linda.ahlkvist@med.lu.se

\begin{abstract}
Stimulation of insulin secretion by short-term glucagon receptor (GCGR) activation is well characterized; however, the effect of long-term GCGR activation on $\beta$-cell function is not known, but of interest, since hyperglucagonemia occurs early during development of type 2 diabetes. Therefore, we examined whether chronic GCGR activation affects insulin secretion in glucose intolerant mice. To induce chronic GCGR activation, high-fat diet fed mice were continuously ( 2 weeks) infused with the stable glucagon analog ZP-GA-1 and challenged with oral glucose and intravenous glucose \pm glucagon-like peptide 1 (GLP1). Islets were isolated to evaluate the insulin secretory response to glucose \pm GLP1 and their pancreas were collected for immunohistochemical analysis. Two weeks of ZP-GA-1 infusion reduced insulin secretion both after oral and intravenous glucose challenges in vivo and in isolated islets. These inhibitory effects were corrected for by GLP1. Also, we observed increased $\beta$-cell area and islet size. We conclude that induction of chronic ZP-GA-1 levels in glucose intolerant mice markedly reduces insulin secretion, and thus, we suggest that chronic activation of the GCGR may contribute to the failure of $\beta$-cell function during development of type 2 diabetes.
\end{abstract}
Key Words
- insulin
- $\beta$-cell function
- glucose intolerance
- chronic glucagon receptor activation

Journal of Endocrinology (2016) 228, 171-178

\section{Introduction}

Islet dysfunction in type 2 diabetes is bi-hormonal involving both defective insulin secretion and augmented glucagon secretion (Unger \& Orci 1975), the latter resulting in chronic elevation of circulating glucagon levels (Larsson \& Ahren 2000, Henkel et al. 2005, Menge et al. 2011). Hyperglucagonemia is associated with worsening of hyperglycemia by maintaining inappropriately high liver glucose production (Unger \& Eisentraut 1964). Whether hyperglucagonemia also contributes to $\beta$-cell failure in type 2 diabetes is not known but a possibility since $\beta$-cells express glucagon receptors (GCGR) (Kawai et al. 1995, Moens et al. 1996).

Under acute conditions, exogenous administration of glucagon potently stimulates insulin secretion (Samols et al. 1966). However, in extrapancreatic tissues, such as liver (Santos \& Blazquez 1982a), brain (Mighiu et al. 2013), and fat (Eaton \& Schade 1973), continuous elevation of glucagon levels results in desensitization of the acute response to glucagon. This has also been observed in humans, in whom acute glucagon action in the liver gradually declines during continuous elevation of glucagon levels (Sherwin et al. 1977). Whether a similar loss of effect of chronic glucagon stimulation exists also for $\beta$-cells is not known, but would be an important factor contributing to the progressive decline of $\beta$-cell function in type 2 diabetes.

However, poor physical and chemical stability of glucagon makes it difficult to use native glucagon for

Published by Bioscientifica Ltd 
long-term experimental studies and for long-term infusions, glucagon has to be stabilized by the use of chemical additions (Webb et al. 2002). In the present study we instead utilized the stable glucagon analog ZP-GA-1 (Riber et al. 2013, 2014) to study the effect of chronic GCGR activation on $\beta$-cell function in the high-fat diet (HFD) fed mouse model of glucose intolerance.

\section{Materials and methods}

\section{Animals}

Female C57BL/6J Bomtac mice (average $20 \mathrm{~g}, 8$ weeks old, Taconic, Skensved, Denmark) were fed a HFD (60\% fat by energy; D12492, Research Diets) during 10 weeks (Winzell $\&$ Ahren 2004). Body weight and food intake were monitored once a week. Food and tap water were provided ad libitum. The animals were housed in groups of six per cage in a temperature-controlled $\left(22^{\circ} \mathrm{C}\right)$ room with artificial lighting maintained on a $12 \mathrm{~h}$ light/12 h darkness cycle with light on at $0600 \mathrm{~h}$ and off at $1800 \mathrm{~h}$. All experimental procedures were approved by the Animal Ethics Committee in Lund, Sweden.

\section{Glucagon analog ZP-GA-1}

The novel glucagon analog ZP-GA-1 (Zealand Pharma A/S, Glostrup, Copenhagen, Denmark) displays superior stability in solution form at physiological $\mathrm{pH}$ compared to native glucagon, with a degradation of $1.8 \%$ compared to $51 \%$ after 7 days in $40{ }^{\circ} \mathrm{C}$ (Riber et al. 2014). Furthermore, ZP-GA-1 retains high potency at the GCGR, with an $\mathrm{EC}_{50}$ of 0.025 vs $0.013 \mathrm{nM}$ for native glucagon, resulting in similar effects on blood glucose in rats (Riber et al. 2013). ZP-GA-1 has been tested at $100 \mathrm{nM}$ for selectivity in a panel screen of 90 GPCRs (Millipore) in which ZP-GA-1 was shown to be selective for the GCGR (K. Fosgerau, personal communication). For the osmotic pump experiments, the compound was formulated in a vehicle consisting of $0.33 \mathrm{M}$ mannitol (Sigma-Aldrich) and $20 \mathrm{mM}$ histidine (Sigma-Aldrich) in water. ZP-GA-1 was prepared in vehicle $1 \mathrm{~h}$ before filling of osmotic pumps.

\section{Osmotic pumps}

Osmotic pumps (Alzet, model 1002, $0.25 \mu \mathrm{l} / \mathrm{h}$ ) were used for delivering a constant infusion of ZP-GA-1 $(1.5,15,150$ or $1500 \mathrm{ng} / \mathrm{h}$ ). The pumps were filled with vehicle or ZPGA-1 and subsequently primed in saline at $37^{\circ} \mathrm{C}$ during $\sim 22 \mathrm{~h}$. The following day, HFD fed mice were divided into two groups and implanted with osmotic pumps containing either vehicle or ZP-GA-1, respectively. In short, mice were given subcutaneously $100 \mu \mathrm{l}$ Temgesic ( $3 \mathrm{mg} / \mathrm{ml}$, Reckitt Benckiser, Slough, UK) in the neck and $50 \mu \mathrm{l}$ Marcain $(2.5 \mathrm{mg} / \mathrm{ml}$, Astra Zeneca, London, UK) at site of incision. Under isofluorane anesthesia and on heating pad, a horizontal incision was made slightly posterior to the neck and a pocket was created under the skin on the left lower back where the osmotic pump was inserted delivery portal first. The wound was closed with surgical glue (Vetbond) and one centrally positioned suture. At 6-h post-op, mice were given a second dose of Temgesic, as described above. The animals were monitored daily until healing of wound and two times a week weight was monitored until end of study.

\section{Oral and intravenous glucose tolerance tests}

For ethical reasons, all in vivo experiments were performed under anesthesia. After 2 weeks of pump implantation, fasted $(5 \mathrm{~h})$ mice were anesthetized with an intraperitoneal injection of midazolam $(0.4 \mathrm{mg} / \mathrm{mouse}$, Dormicum, Hoffman-La Roche) and a combination of fluanisone $(0.9 \mathrm{mg} / \mathrm{mouse})$ and fentanyl $(0.02 \mathrm{mg} / \mathrm{mouse}$, Hypnorm, Janssen, Beerse, Belgium). These agents in combination have been shown to have no effect on basal plasma glucose and insulin levels (Zuurbier et al. 2014). After 2-week infusion of ZP-GA-1 (1.5, 15, 150 and $1500 \mathrm{ng} / \mathrm{h})$, an oral glucose tolerance test (OGTT) was performed where the mice were gavaged $(0.5 \mathrm{ml})$ with glucose $(75 \mathrm{mg} /$ mouse) . For the highest ZP-GA-1 dose (1500 ng/h), an intravenous glucose tolerance test (IVGTT) was performed where the mice were injected with glucose $(0.35 \mathrm{~g} / \mathrm{kg}$, Sigma) in a tail vein with or without glucagon-like peptide 1 (GLP1) ( $3 \mathrm{nmol} / \mathrm{kg}$, Sigma). Blood samples were collected at different time points into heparinized tubes from the retrobulbar, intraorbital, capillary plexus. For determination of plasma ZP-GA-1 levels, blood samples were collected into heparinized tubes containing Pierce protease inhibitor (Thermo Scientific, Waltham, MA, USA). After collection, all blood samples were immediately centrifuged $\left(4^{\circ} \mathrm{C}\right)$ and plasma was stored $\left(-20^{\circ} \mathrm{C}\right)$ for subsequent analysis.

\section{Islet experiments}

Pancreatic islets from vehicle and ZP-GA-1 infused (2-week infusion) HFD fed mice were isolated by collagenase digestion and handpicked under the microscope. Batches of freshly isolated islets were pre-incubated in HEPES balanced salt solution containing $125 \mathrm{mmol} / \mathrm{l} \mathrm{NaCl}$,

Published by Bioscientifica Ltd. 
$5.9 \mathrm{mmol} / \mathrm{l} \mathrm{KCl}, 1.28 \mathrm{mmol} / 1 \mathrm{CaCl}_{2}, 1.2 \mathrm{mmol} / 1 \mathrm{MgCl}_{2}$, $25 \mathrm{mmol} / \mathrm{l} \mathrm{HEPES}$ (pH 7.4), $5.6 \mathrm{mmol} / 1$ glucose and $0.1 \%$ fatty acid free BSA (Boehringer, Mannheim, Germany) at $37^{\circ} \mathrm{C}$ during $60 \mathrm{~min}$. Thereafter, islets in groups of three were incubated in $200 \mu \mathrm{l}$ of the above described buffer with $2.8,5.6,8.3,11.1$ and $16.7 \mathrm{mM}$ glucose as well as $11.1 \mathrm{mM}$ glucose + GLP1 $(100 \mathrm{nM})$ at $37^{\circ} \mathrm{C}$ during $30 \mathrm{~min}$. Aliquots of the buffer were collected and stored at $-20^{\circ} \mathrm{C}$ until analysis of insulin levels.

\section{Immunohistochemistry}

Pancreata from vehicle and ZP-GA-1 infused (2-week infusion) HFD fed mice were isolated, weighed and fixed in $4 \%$ formaldehyde overnight. Following dehydration, tissues were embedded in paraffin and sectioned $(5 \mu \mathrm{m})$. Antigen retrieval of sections was performed in sodium citrate buffer $(10 \mathrm{mmol} / \mathrm{l}$ sodium citrate, $0.05 \%$ Tween 20 , $\mathrm{pH}$ 6.0) at $95^{\circ} \mathrm{C}$ for $20 \mathrm{~min}$ and permeabilized in $0.25 \%$ Triton X-100 and $0.1 \%$ BSA in PBS. Sections were incubated overnight at $4{ }^{\circ} \mathrm{C}$ with primary antibodies against insulin (polyclonal guinea pig anti-insulin antibody; EuroProxima, Arnhem, The Netherlands) and glucagon (monoclonal mouse anti-glucagon antibody; Abcam, Cambridge, UK). Detection of immuno-labeled epitopes was made by the fluorescent secondary antibodies DyLight 594 conjugated rabbit anti-guinea pig (polyclonal; Abcam) and DyLight 488 conjugated donkey anti mouse (polyclonal; Abcam), both diluted 1:200. Fluorescence images were captured with an Olympus DP72 microscope and processed with CellSens dimension software. $\beta$-cell mass was determined by measuring the insulin-positive area per islet and islet size was assessed by determination of insulin + area and glucagon + area per islet from 40 islets per animal, divided on three different sections (separated by $200 \mu \mathrm{m}$ ) per pancreas.

\section{Plasma analysis}

Plasma glucose was measured with the glucose oxidase method using 2,2'-azino-bis(3-ethyl-benzothialozine-6sulphonate) as a substrate with the absorbance measured at $420 \mathrm{~nm}$ on a microtiter plate reader (Fluostar/Polarstar Galaxy; BMG Labtechnologies, Offenburg, Germany). Insulin was analyzed with sandwich immunoassay technique (ELISA) using double monoclonal antibodies against insulin (Mercodia, Uppsala, Sweden). The assay for determination of glucagon analog ZP-GA-1 in plasma was based on sample preparation by immuno-precipitation using Dynabeads M-270 Epoxy (Life Technology AS, Oslo, Norway) followed by detection by electrospray LC-MS/MS using Xevo TQ-S mass spectrometer (Waters Corporation, Manchester, UK). The method has a lower limit of quantification (LLOQ) of $0.04 \mathrm{nmol} / \mathrm{l}$.

\section{Statistical analysis}

Data are reported as mean values \pm s.E.M. Statistical significances were assessed by using Student's $t$-test or ANOVA. Glucose elimination was quantified using the glucose elimination constant $\left(\mathrm{K}_{\mathrm{G}}\right)$, calculated as the slope of the logarithmic transformation of circulating glucose between 30 and $120 \mathrm{~min}$ (for OGTT) and between 1 and $50 \mathrm{~min}$ (for IVGTT). Suprabasal area under the curve (sAUC) was calculated by the trapezoidal rule for insulin data during time intervals 0-60 min (for OGTT) and 0-10 min (for IVGTT). Basal insulin sensitivity was assessed by the QUICKI index $1 /(\log$ (basal insulin)+ $\log$ (basal glucose)). Significant statistical difference was considered at $P<0.05$ whereby asterisks indicate the probability level of random difference between the groups.

\section{Results}

Basal glucose, but not basal insulin and body weight, are elevated by ZP-GA-1

There was no difference in body weight between the groups before or after osmotic pump implantation, but a significantly higher basal glucose level in the ZP-GA-1 infused mice compared to control $(P<0.01)$ (Table 1). Basal insulin levels were similar between groups (Table 1). Also, there was no difference in basal insulin sensitivity (QUICKI) between the two groups (Table 1).

\section{Insulin response to oral glucose is reduced by ZP-GA-1}

A 2-week infusion of ZP-GA-1 (1.5, 15, 150 and $1500 \mathrm{ng} / \mathrm{h})$ dose dependently reduced the insulin response to oral

Table 1 Body weight, basal glucose and insulin levels and basal insulin sensitivity (QUICKI) in high-fat diet fed mice infused with vehicle or ZP-GA-1 (1500 ng/h) during 2 weeks

\begin{tabular}{l} 
\\
\hline Body weight (g) (day 0) \\
Body weight (g) (day 14) \\
Basal glucose (mM) \\
Basal insulin (pM) \\
QUICKI
\end{tabular}

\begin{tabular}{c}
\hline Vehicle \\
\hline $29.3 \pm 0.8$ \\
$30.3 \pm 0.7$ \\
$9.8 \pm 0.3$ \\
$293 \pm 28$ \\
$0.294 \pm 0.004$
\end{tabular}

\begin{tabular}{c}
\hline ZP-GA-1 \\
\hline $31.6 \pm 0.8$ \\
$31.8 \pm 0.8$ \\
$11.6 \pm 0.6^{* *}$ \\
$284 \pm 39$ \\
$0.292 \pm 0.005$ \\
\hline
\end{tabular}

Means \pm S.E.M. are shown, $n=22-23$ mice. ${ }^{*} P<0.01$.

Published by Bioscientifica Ltd. 
glucose (Fig. 1A). For the highest ZP-GA-1 dose $(1500 \mathrm{ng} / \mathrm{h})$, postprandial $(120 \mathrm{~min})$ ZP-GA-1 levels in plasma were measured to $136 \pm 19 \mathrm{pM}$ (Fig. 1B), which is $\sim 100$ times higher than that of native basal glucagon in mice (Malmgren \& Ahren 2015), however, only two times higher than that of the glucagon response to hypoglycemia (Berglund et al. 2008). The elevation of plasma ZPGA-1 resulted in a significant lowering of insulin secretion in response to glucose compared to control (Fig. 1D), also shown with $30 \mathrm{~min}$ sAUC insulin levels (Fig. 1F). Also, there was a trend for elevation of postprandial plasma glucose levels in the ZP-GA-1 treated group (60 min, $P=0.06$; 120 min, $P=0.07$ ) (Fig. 1C), which was associated with reduced glucose elimination $\left(\mathrm{K}_{\mathrm{G}}\right)(P<0.05)$ (Fig. 1E).

\section{Insulin response to intravenous glucose is reduced by ZP-GA-1 and corrected for by GLP1}

During IVGTT, chronic (2 weeks) infusion of ZP-GA-1 via osmotic pump significantly reduced insulin levels compared to control (1 min, $P<0.05 ; 5$ min, $P<0.01$;
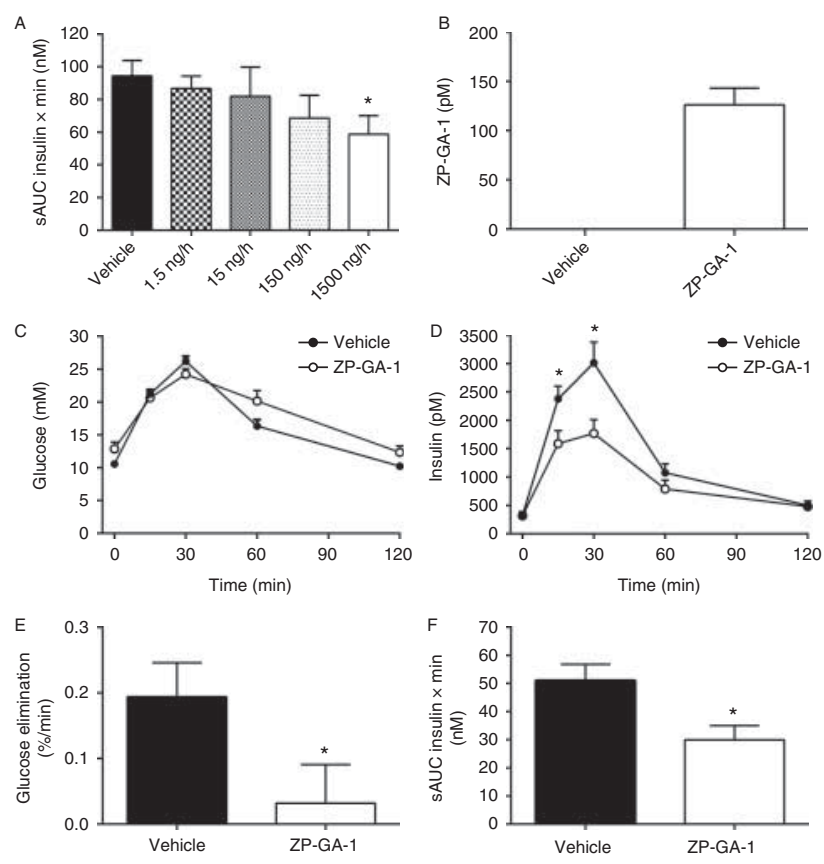

Figure 1

Two-week chronic GCGR activation reduced the insulin response to oral glucose. (A) SAUC insulin (0-60 min) during OGTT in high-fat diet fed mice infused with vehicle (black bars) or glucagon analog ZP-GA-1 in various doses $(0.15,15,150$ and $1500 \mathrm{ng} / \mathrm{h}$ ) (hatched-white bars). For the highest ZP-GA-1 dose (1500 ng/h) (white circles/bars), plasma levels of (B) ZP-GA-1, (C) glucose, (D) insulin, (E) glucose elimination $\mathrm{K}_{\mathrm{G}}(30-120 \mathrm{~min}$ ) and $(\mathrm{F})$ sAUC insulin (0-60 min) were determined compared to vehicle (black circles/bars). Means \pm S.E.M. are shown, $n=10$ mice/group. ${ }^{*} P<0.05$.
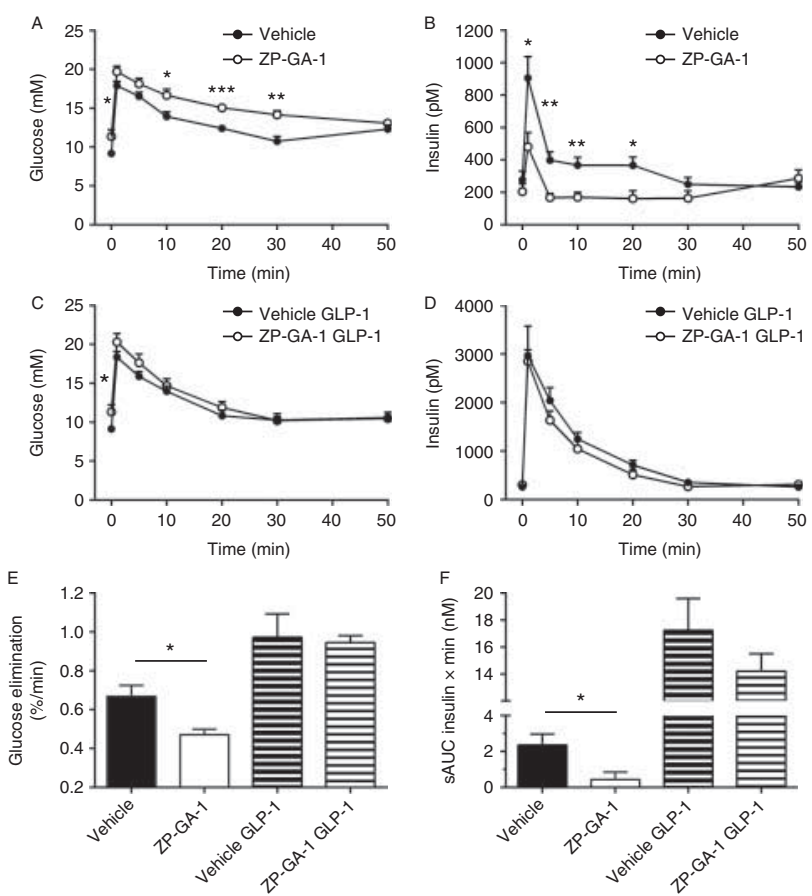

Figure 2

Two-week chronic GCGR activation reduced the insulin response to intravenous glucose and was corrected for by GLP1. Plasma levels of (A) glucose and (B) insulin during IVGTT, co-injected with GLP-1 $(3 \mathrm{nmol} / \mathrm{kg})$ ( $C$ and $D$ ), in high-fat diet fed mice infused with vehicle (black circles) or glucagon analog ZPGA-1 (1500 ng/h) (white circles). (E) Glucose elimination $\left(K_{G}\right)(1-20 \mathrm{~min})$ and $(F)$ sAUC insulin (0-10 $\mathrm{min}$ ) data are also shown for all groups. Means \pm S.E.M. are shown, $n=6-7$ mice/group. ${ }^{*} P<0.05,{ }^{* *} P<0.01$, and $* * * P<0.001$.

10 min, $P<0.01 ; 20$ min, $P<0.05$ ) (Fig. 2B), also shown by lower $10 \mathrm{~min}$ AUC data (Fig. 2F). Also, we observed increased plasma glucose levels compared to control mice (10 min, $P<0.05 ; 20 \mathrm{~min}, P<0.001 ; 30 \mathrm{~min}$, $P<0.01$ ) (Fig. 2A), which was associated with reduced glucose elimination $\left(\mathrm{K}_{\mathrm{G}}\right)$ (Fig. $2 \mathrm{E}$ ). After co-injection of GLP1 with glucose there were no longer any difference in plasma glucose (Fig. 2C) and insulin (Fig. 2D) levels between the groups.

\section{Insulin secretion in isolated islets is reduced by ZP-GA-1 and corrected for by GLP1}

Isolated islets from the mice infused with ZP-GA-1 had reduced insulin secretion when incubated in moderate to high glucose concentrations compared to control $(8.3 \mathrm{mM}$, $P<0.001 ; 11.1 \mathrm{mM}, P<0.05 ; 16.7 \mathrm{mM}, P<0.05)$, whereas responses to basal and lower glucose concentrations were unchanged between groups (Fig. 3). Also, the insulinotropic effects of GLP1 in the presence of $11.1 \mathrm{mM}$ glucose were not different between groups (Fig. 3).

Published by Bioscientifica Ltd 


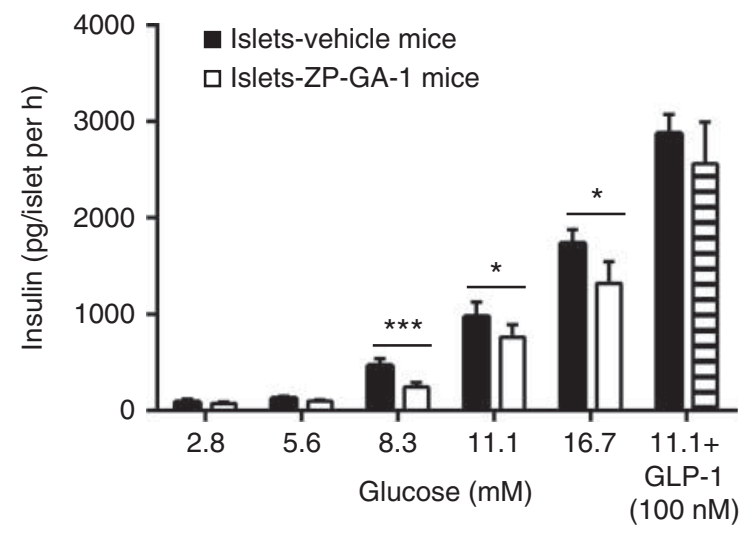

Figure 3

In isolated islets from ZP-GA-1 infused mice, the insulin response to glucose was reduced and corrected for by GLP1. Insulin responses $(1 \mathrm{~h})$ of islets, isolated from high-fat diet fed mice infused with vehicle (black bars) or glucagon analog ZP-GA-1 (1500 ng/h) (white bars), to glucose at 2.8, 5.6, $8.3,11.1$ or $16.7 \mathrm{mM}$ or at $11.1 \mathrm{mM}$ with GLP1 (100 nM, striped bar). Means \pm s.E.M. are shown, $n=6$ mice in each group. ${ }^{*} P<0.05$ and $* * * P<0.001$.

\section{$\beta$-cell area and islet size are increased by ZP-GA-1}

Representative images of islets from vehicle and ZP-GA-1 infused mice, fluorescently stained for insulin and glucagon, are show in Fig. 4. There was no difference in the pancreas weight of vehicle and ZP-GA-1 infused mice (Table 2). The immunohistochemical analysis of the pancreatic sections from the ZP-GA-1 infused mice showed increased area of insulin fluorescent staining per islet compared to control $(P<0.01)$ (Table 2$)$. There was a trend also for increased area of glucagon fluorescent staining per islet; however, it was not statistically different between groups (Table 2). Islet size, i.e., the combined area of insulin and glucagon fluorescent staining, was increased in the ZP-GA-1 infused mice compared to control $(P<0.01)$ (Table 2$)$.

\section{Discussion}

Hyperglucagonemia is an important factor for type 2 diabetes which contributes to increased hepatic glucose production (Rizza 2010). In spite of this, however, little is known about the role of chronically elevated glucagon levels for $\beta$-cell function. A reason for this is the lack of appropriate models of long-term glucagon action, which in part is due to difficulties in administering native glucagon long-term because of poor chemical and physical stability. Therefore, in the current study, we administered a stable glucagon analog (ZP-GA-1) to mice fed a HFD to create a novel model for studying effects of chronic GCGR activation on $\beta$-cell function. The HFD fed mice do not develop hyperglucagonemia (Ahlkvist et al. 2013) which allowed us to study the impact of chronic GCGR stimulation on glucose tolerance in a glucose intolerant model without the confounding factor of endogenous hyperglucagonemia. In these mice, 2-week ZP-GA-1 infusion markedly reduced the insulin response to oral glucose. Thus, the ability of these HFD fed mice to compensate for insulin resistance by increasing insulin
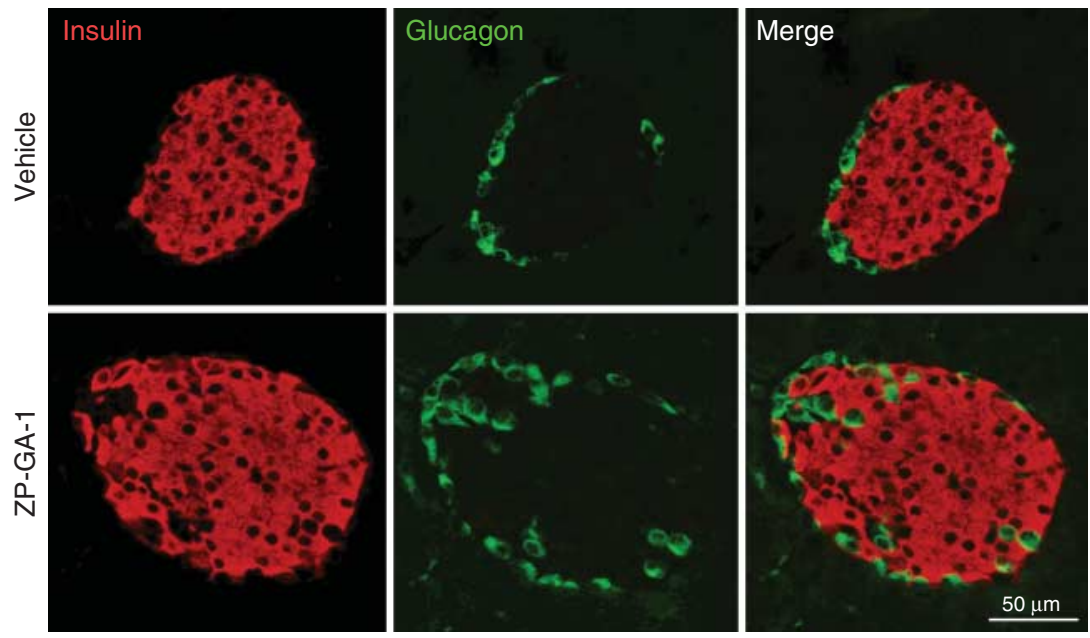

Figure 4

Representative images showing insulin + area (red staining), glucagon + area (green staining) and merge (red and green staining combined) of 120 islets per pancreas collected from high-fat diet fed mice infused with vehicle (upper panel) or glucagon analog ZP-GA-1 (1500 ng/h) (lower panel) during 2 weeks. Scale bar $50 \mu \mathrm{m}, n=6$ mice/group. 
Table 2 Pancreas weight, islet area, $\beta$-cell area and $\alpha$-cell area of pancreatic sections from high-fat diet fed mice infused with vehicle or ZP-GA-1 (1500 ng/h) during 2 weeks. Means \pm s.E.M. are shown, $n=6$ mice (of which 120 islets were analyzed per animal)

Pancreas weight $(\mathrm{mg})$
Islet area $\left(\mu \mathrm{m}^{2}\right)$
$\beta$-cell area $\left(\mu \mathrm{m}^{2}\right)$
$\alpha$-cell area $\left(\mu \mathrm{m}^{2}\right)$

\begin{tabular}{c}
\hline Vehicle \\
\hline $298 \pm 11$ \\
$16503 \pm 1564$ \\
$13481 \pm 1323$ \\
$2378 \pm 314$ \\
\hline
\end{tabular}

\begin{tabular}{c}
\hline ZP-GA-1 \\
\hline $307 \pm 10$ \\
$27250 \pm 1975$ \\
$23526 \pm 1790$ ** \\
$3118 \pm 313$ \\
\hline
\end{tabular}

$* * P<0.01$.

secretion is reduced, which leads to significant reductions in glucose clearance. However, in spite of different insulin responses, plasma glucose levels were similar between groups, which likely reflect the underlying insulin resistance. When bypassing the gut, challenging $\beta$-cells with intravenous glucose revealed, similarly, impaired insulin secretion. Interestingly, under these conditions we also observed a compensatory increase in $\beta$-cell area. The observed defect in glucose-stimulated insulin secretion was corrected for by GLP1.

Chronic exposures to target tissues of a wide range of hormones has been shown to result in desensitization of effect, exemplified by tissue resistance to insulin (Rizza et al. 1985, Paolisso et al. 1988) and adrenaline (Stallknecht et al. 1997). In line with this, desensitization of glucagon action has previously been shown in various organs that are responsive to glucagon (Eaton \& Schade 1973, Santos \& Blazquez 1982a, Mighiu et al. 2013). In chickens, twice daily injections of glucagon during 2 weeks resulted in increased fat deposition, indicative of reduced lipolytic and anti-lipogenic effects of glucagon (Cogburn 1991), with supporting findings in cultured adipocytes (Oscar 1996). Also, in rats injected with glucagon every $8 \mathrm{~h}$ during 4 days, impairment in hepatic glucagon signaling was observed (Santos \& Blazquez 1982b). In the present study, we observed a similar desensitization effect on insulin secretion in HFD fed mice in vivo in response to glucose after 2-week ZP-GA-1 infusion. Since we demonstrated that insulin secretion was impaired also in isolated islets which were removed from the animals after 2 -week ZP-GA-1 infusion, our results show that a direct $\beta$-cell effect also contributes to impaired $\beta$-cell function during chronic GCGR activation. This does not exclude that an indirect effect may also contribute. Thus, it has previously been shown that glucagon increases the liver expression of kisspeptin (Song et al. 2014), which has been shown to inhibit insulin secretion in mice (Vikman \& Ahren 2009), which could be a contributing possibility in our studies. The important conclusion is, however, that chronic GCGR activation is detrimental for $\beta$-cell function.

Consistent with the idea that chronic glucagon may be casually linked to $\beta$-cell dysfunction, glucagon has been shown to play an important role in sensitizing glucosestimulated insulin secretion (Pipeleers et al. 1985, Huypens et al. 2000), by maintaining appropriate levels of intracellular cAMP within the $\beta$-cells (Cypess et al. 1999). Indeed, when boosting endogenous glucagon signaling, by overexpressing GCGRs specifically on pancreatic $\beta$-cells, glucose-stimulated insulin secretion was enhanced (Omar et al. 2014). This is compatible with a conclusion of a reduced receptor sensitization explaining the impaired insulin secretion by chronic GCGR activation. Interestingly, the impaired insulin secretion was corrected for by GLP1, which like glucagon also signals through cAMP (Drucker et al. 1987). In line with this, it has been shown that type 2 diabetics who have reduced first-phase insulin responses to glucose do have improved first-phase responses to the cAMP-elevating agent isoprenaline (Robertson \& Porte 1973), pointing to the presence of intact cellular signaling components necessary for firstphase insulin secretion. These collective observations may suggest that defects in insulin secretion seen during chronic GCGR activation may be caused by desensitization of glucagon action, mediated through cAMP. Previous studies have implicated both the loss of GCGRs in the cell membrane and defects in downstream signaling pathways as part of glucagon-mediated desensitization processes (Premont \& Iyengar 1988), however this needs to be further investigated during long-term conditions. In the islet experiments, the effect of GLP1 was not as pronounced, which implies that peripheral factors, such as nerves, are also of importance for the insulin response to GLP1 (Nishizawa et al. 1996).

Interestingly, immunohistochemical analysis of pancreatic sections revealed that infusion of ZP-GA-1 during 2 weeks significantly increased islet size, without any changes in pancreas weight. The increase in islet size was well correlated with an increase in the area of insulin staining, which is an indirect estimate of $\beta$-cell mass. The mechanism of this effect of ZP-GA-1 is not known, but the failure of $\beta$-cells to secrete sufficient insulin during chronic GCGR activation, to cover the need of target tissues, may contribute to the expansion of $\beta$-cell mass. Indirectly, increased hepatic glucose production, due to chronic ZPGA-1 levels, may put a further strain on the $\beta$-cells and potentially contribute to the increase in $\beta$-cell mass. Furthermore, although there was no difference in basal

Published by Bioscientifica Ltd. 
insulin sensitivity, we cannot rule out that dynamic changes in insulin sensitivity during the course of the 2-week study were involved in the observed changes in $\beta$-cell mass. Although not significant, we observed a trend for increased glucagon staining, and thus, increased $\alpha$-cell area may to some extent also contribute to the increase in islet size.

In the present study, continuous ( 2 weeks) infusion of the glucagon analog ZP-GA-1 in glucose intolerant mice is used as a surrogate method for studying chronic GCGR activation in humans. Thus, there are several limitations to this study that needs to be addressed. First, although the HFD fed mouse model in many ways resembles the condition of pre-diabetes in humans (Winzell \& Ahren 2004), the current findings also need to be validated in human studies. Concerning timing and administration, continuous infusion of ZP-GA-1 does not reflect pulsatile glucagon secretion (Gylfe \& Gilon 2014), and thus, lack of dynamic plasma ZP-GA-1 levels may in itself cause desensitization of glucose-stimulated insulin secretion. However, since fasting glucagon levels are elevated $\sim 40 \%$ in type 2 diabetes (Menge et al. 2011), continuous elevation of blood glucagon levels is in this regard a suitable simulator of chronic GCGR activation. Furthermore, 2 weeks of ZP-GA-1 infusion is a limited time period and therefore we cannot draw any conclusions on the longterm effects of ZP-GA-1 on $\beta$-cell function. Concerning the glucagon analog, it is not known whether ZP-GA-1 may act differently on the GCGR, resulting in downstream intracellular signals that are different from that of native glucagon. Therefore, whether the current reduction in insulin secretion, observed during ZP-GA-1 infusion, is also seen during hyperglucagonemia remains to be established.

In conclusion, a 2-week infusion of the glucagon analog ZP-GA-1 in high-fat fed mice results in reduced insulin secretion which is corrected for by GLP1. This suggests that chronic GCGR activation may contribute to the progressive $\beta$-cell dysfunction in type 2 diabetes which further underlines that hyperglucagonemia is a target for treatment of type 2 diabetes.

\section{Declaration of interest}

$L A, B O$ and $B A$ have no conflicts of interest to disclose. A V and $K F$ are employees at Zealand Pharma and K F owns stocks in Zealand Pharma.

\section{Funding}

The authors acknowledge the Swedish Research Council (grant number 6834), Region Skåne and Faculty of Medicine, Lund University, for financial support.

\section{Author contribution statement}

$\mathrm{L}$ A contributed with the design of the study, undertaking of the experiments, analyzes and statistics, interpretation and discussion of the data and writing the manuscript. B O contributed with the design of the study and gave comments to the manuscript. A $V$ contributed with design of the study and analysis of plasma ZP-GA-1. K F contributed with the design of the study and gave comments to the manuscript. B A contributed with design of the study, interpretation and discussion of the data and writing the manuscript. L A is the guarantor of this work and, as such, had full access to all the data in the study and takes responsibility for the integrity of the data and the accuracy of the data analysis.

\section{Acknowledgments}

The authors thank Zealand Pharma for kindly providing us with the glucagon analog ZP-GA-1. We are grateful to laboratory technician Kristina Andersson for expert technical assistance.

\section{References}

Ahlkvist L, Brown K \& Ahren B 2013 Upregulated insulin secretion in insulin-resistant mice: evidence of increased islet GLP1 receptor levels and GPR119-activated GLP1 secretion. Endocrine Connections 2 69-78. (doi:10.1530/EC-12-0079)

Berglund ED, Li CY, Poffenberger G, Ayala JE, Fueger PT, Willis SE, Jewell MM, Powers AC \& Wasserman DH 2008 Glucose metabolism in vivo in four commonly used inbred mouse strains. Diabetes 57 1790-1799. (doi:10.2337/db07-1615)

Cogburn LA 1991 Endocrine manipulation of body composition in broiler chickens. Critical Reviews in Poultry Biology 3 283-305.

Cypess AM, Unson CG, Wu CR \& Sakmar TP 1999 Two cytoplasmic loops of the glucagon receptor are required to elevate cAMP or intracellular calcium. Journal of Biological Chemistry 274 19455-19464. (doi:10.1074/ jbc.274.27.19455)

Drucker DJ, Philippe J, Mojsov S, Chick WL \& Habener JF 1987 Glucagonlike peptide I stimulates insulin gene expression and increases cyclic AMP levels in a rat islet cell line. PNAS 84 3434-3438. (doi:10.1073/ pnas.84.10.3434)

Eaton RP \& Schade DS 1973 Glucagon resistance as a hormonal basis for endogenous hyperlipaemia. Lancet 1 973-974. (doi:10.1016/S01406736(73)91605-X)

Gylfe E \& Gilon P 2014 Glucose regulation of glucagon secretion. Diabetes Research and Clinical Practice 103 1-10. (doi:10.1016/j.diabres.2013. 11.019)

Henkel E, Menschikowski M, Koehler C, Leonhardt W \& Hanefeld M 2005 Impact of glucagon response on postprandial hyperglycemia in men with impaired glucose tolerance and type 2 diabetes mellitus. Metabolism 54 1168-1173. (doi:10.1016/j.metabol.2005.03.024)

Huypens P, Ling Z, Pipeleers D \& Schuit F 2000 Glucagon receptors on human islet cells contribute to glucose competence of insulin release. Diabetologia 43 1012-1019. (doi:10.1007/s001250051484)

Kawai K, Yokota C, Ohashi S, Watanabe Y \& Yamashita K 1995 Evidence that glucagon stimulates insulin secretion through its own receptor in rats. Diabetologia 38 274-276. (doi:10.1007/BF00400630)

Larsson H \& Ahren B 2000 Islet dysfunction in insulin resistance involves impaired insulin secretion and increased glucagon secretion in postmenopausal women with impaired glucose tolerance. Diabetes Care 23 650-657. (doi:10.2337/diacare.23.5.650)

Malmgren S \& Ahren B 2015 DPP-4 inhibition contributes to the prevention of hypoglycaemia through a GIP-glucagon counterregulatory axis in mice. Diabetologia 58 1091-1099. (doi:10.1007/s00125015-3518-7) 
Menge BA, Gruber L, Jorgensen SM, Deacon CF, Schmidt WE, Veldhuis JD, Holst JJ \& Meier JJ 2011 Loss of inverse relationship between pulsatile insulin and glucagon secretion in patients with type 2 diabetes. Diabetes 60 2160-2168. (doi:10.2337/db11-0251)

Mighiu PI, Yue JT, Filippi BM, Abraham MA, Chari M, Lam CK, Yang CS, Christian NR, Charron MJ \& Lam TK 2013 Hypothalamic glucagon signaling inhibits hepatic glucose production. Nature Medicine 19 766-772. (doi:10.1038/nm.3115)

Moens K, Heimberg H, Flamez D, Huypens P, Quartier E, Ling Z, Pipeleers D, Gremlich S, Thorens B \& Schuit F 1996 Expression and functional activity of glucagon, glucagon-like peptide I, and glucose-dependent insulinotropic peptide receptors in rat pancreatic islet cells. Diabetes $\mathbf{4 5}$ 257-261. (doi:10.2337/diab.45.2.257)

Nishizawa M, Nakabayashi H, Uchida K, Nakagawa A \& Niijima A 1996 The hepatic vagal nerve is receptive to incretin hormone glucagon-like peptide-1, but not to glucose-dependent insulinotropic polypeptide, in the portal vein. Journal of the Autonomic Nervous System 61 149-154. (doi:10.1016/S0165-1838(96)00071-9)

Omar B, Sorhede-Winzell M \& Ahren B 2014 Conditional glucagon receptor overexpression has multi-faceted consequences for $\beta$-cell function. Metabolism 63 1568-1576. (doi:10.1016/j.metabol.2014. 09.004)

Oscar TP 1996 Down-regulation of glucagon receptors on the surface of broiler adipocytes. Poultry Science 75 1027-1034. (doi:10.3382/ps. 0751027)

Paolisso G, Sgambato S, Torella R, Varricchio M, Scheen A, D'Onofrio F \& Lefebvre PJ 1988 Pulsatile insulin delivery is more efficient than continuous infusion in modulating islet cell function in normal subjects and patients with type 1 diabetes. Journal of Clinical Endocrinology and Metabolism 66 1220-1226. (doi:10.1210/jcem-66-6-1220)

Pipeleers DG, Schuit FC, in't Veld PA, Maes E, Hooghe-Peters EL, Van de Winkel M \& Gepts W 1985 Interplay of nutrients and hormones in the regulation of insulin release. Endocrinology 117 824-833. (doi:10.1210/endo-117-3-824)

Premont RT \& Iyengar R 1988 Glucagon-induced desensitization of adenylyl cyclase in primary cultures of chick hepatocytes. Evidence for multiple pathways. Journal of Biological Chemistry 263 16087-16095.

Riber DM, Giehm L, Andersen MS, Østerlund T, Nørregaard P, Valeur A \& Neerup TS 2013 A novel glucagon analogue, ZP-GA-1, displays increased chemical and physical stability in liquid formulation. Diabetes 62(Suppl 1) A99-172.

Riber DV, Svendgaard M, Macchi F, Giehm L, Fosgerau K \& Noerregaard P 2014 The novel glucagon analogue ZP-GA-1 has superior physicochemical properties while maintaining the pharmacokinetic and pharmacodynamic profile of native glucagon. Diabetes $\mathbf{6 3}$ (Suppl 1) A103-A170.

Rizza RA 2010 Pathogenesis of fasting and postprandial hyperglycemia in type 2 diabetes: implications for therapy. Diabetes 59 2697-2707. (doi:10.2337/db10-1032)
Rizza RA, Mandarino LJ, Genest J, Baker BA \& Gerich JE 1985 Production of insulin resistance by hyperinsulinaemia in man. Diabetologia 28 70-75. (doi:10.1007/BF00279918)

Robertson RP \& Porte D Jr 1973 The glucose receptor. A defective mechanism in diabetes mellitus distinct from the $\beta$ adrenergic receptor. Journal of Clinical Investigation 52 870-876. (doi:10.1172/JCI107251)

Samols E, Marri G \& Marks V 1966 Interrelationship of glucagon, insulin and glucose. The insulinogenic effect of glucagon. Diabetes 15 855-866. (doi:10.2337/diab.15.12.855)

Santos A \& Blazquez E 1982a Direct evidence of a glucagon-dependent regulation of the concentration of glucagon receptors in the liver. European Journal of Biochemistry 121 671-677. (doi:10.1111/j.14321033.1982.tb05838.x)

Santos A \& Blazquez E 1982b Regulatory effect of glucagon on its own receptor concentrations and target-cell sensitivity in the rat. Diabetologia 22 362-371. (doi:10.1007/BF00253583)

Sherwin RS, Hendler R \& Felig P 1977 Influence of physiologic hyperglucagonemia on urinary glucose, nitrogen, and electrolyte excretion in diabetes. Metabolism 26 53-58. (doi:10.1016/0026-0495 (77)90127-5)

Song WJ, Mondal P, Wolfe A, Alonso LC, Stamateris R, Ong BW, Lim OC, Yang KS, Radovick S, Novaira HJ et al. 2014 Glucagon regulates hepatic kisspeptin to impair insulin secretion. Cell Metabolism 19 667-681. (doi:10.1016/j.cmet.2014.03.005)

Stallknecht B, Bulow J, Frandsen E \& Galbo H 1997 Desensitization of human adipose tissue to adrenaline stimulation studied by microdialysis. Journal of Physiology 500 271-282. (doi:10.1113/jphysiol.1997. sp022017)

Unger RH \& Eisentraut AM 1964 Studies of the physiologic role of glucagon. Diabetes 13 563-568. (doi:10.2337/diab.13.6.563)

Unger RH \& Orci L 1975 The essential role of glucagon in the pathogenesis of diabetes mellitus. Lancet 1 14-16. (doi:10.1016/S0140-6736 (75)92375-2)

Vikman J \& Ahren B 2009 Inhibitory effect of kisspeptins on insulin secretion from isolated mouse islets. Diabetes, Obesity \& Metabolism 11(Suppl 4) 197-201. (doi:10.1111/j.1463-1326.2009.01116.x)

Webb GC, Akbar MS, Zhao C, Swift HH \& Steiner DF 2002 Glucagon replacement via micro-osmotic pump corrects hypoglycemia and $\alpha$-cell hyperplasia in prohormone convertase 2 knockout mice. Diabetes $\mathbf{5 1}$ 398-405. (doi:10.2337/diabetes.51.2.398)

Winzell MS \& Ahren B 2004 The high-fat diet-fed mouse: a model for studying mechanisms and treatment of impaired glucose tolerance and type 2 diabetes. Diabetes 53(Suppl 3) S215-S219. (doi:10.2337/diabetes. 53.suppl_3.S215)

Zuurbier CJ, Koeman A, Houten SM, Hollmann MW \& Florijn WJ 2014 Optimizing anesthetic regimen for surgery in mice through minimization of hemodynamic, metabolic, and inflammatory perturbations. Experimental Biology and Medicine 239 737-746. (doi:10.1177/1535370214524877)

Received in final form 2 December 2015

Accepted 22 December 2015

Accepted Preprint published online 23 December 2015 http://joe.endocrinology-journals.org DOI: 10.1530/JOE-15-0371
(C) 2016 Society for Endocrinology Printed in Great Britain
Published by Bioscientifica Ltd. 